\title{
Simulation and Prediction of the Vickers Hardness of AZ91 Magnesium Alloy Using Artificial Neural Network Model
}

\author{
Alaa F. Abd El-Rehim ${ }^{1,2, *}$, Heba Y. Zahran ${ }^{1,2}$, Doaa M. Habashy ${ }^{2}$ and Hana M. Al-Masoud ${ }^{1}$ \\ 1 Physics Department, Faculty of Science, King Khalid University, P.O. Box 9004, Abha 61413, Saudi Arabia; \\ heldemardash@kku.edu.sa (H.Y.Z.); 435820327@kku.edu.sa (H.M.A.-M.) \\ 2 Physics Department, Faculty of Education, Ain Shams University, P.O. Box 5101, Heliopolis, Roxy, \\ Cairo 11771, Egypt; doaamahmoud@edu.asu.edu.eg \\ * Correspondence: alaa.abdelrehim@kku.edu.sa
}

Received: 9 February 2020; Accepted: 8 April 2020; Published: 10 April 2020

\begin{abstract}
In this study, an artificial neural network (ANN) model was used to simulate and predict the Vickers hardness of AZ91 magnesium alloy. The samples of AZ91 alloy were aged at different temperatures $\left(T_{a}=100\right.$ to $\left.300^{\circ} \mathrm{C}\right)$ for different durations $\left(t_{a}=4\right.$ to $\left.192 \mathrm{~h}\right)$ followed by water quenching at $25^{\circ} \mathrm{C}$. The age-hardening response of the samples was investigated by hardness measurements. The microstructure investigations showed that only discontinuous precipitates formed at low aging temperatures $\left(100\right.$ and $150{ }^{\circ} \mathrm{C}$ ), while continuous precipitates invaded all the samples at a high aging temperature $\left(300^{\circ} \mathrm{C}\right)$. Both discontinuous and continuous precipitates formed at the intermediate aging temperatures $\left(200\right.$ and $\left.250^{\circ} \mathrm{C}\right)$. X-ray diffraction (XRD) analysis revealed that the microstructure comprised two phases: The $\alpha-\mathrm{Mg}$ matrix and intermetallic $\beta-\mathrm{Mg}_{17} \mathrm{Al}_{12}$ phase. The alteration of the crystalline lattice parameters $a, c$, and $c / a$ ratio with the aging time at various aging temperatures was also investigated. Both $c$ and $c / a$ ratio had the same behavior with aging time while $a$ had an inverse trend. The observed variations of the lattice parameters were attributed to the mode of precipitation in AZ91 alloy. The ANN findings for the simulation and prediction perfectly conformed to the experimental data.
\end{abstract}

Keywords: AZ91 magnesium alloys; age-hardening response; microstructure evolution; $\beta-\mathrm{Mg}_{17} \mathrm{Al}_{12}$ phase; artificial neural network model

\section{Introduction}

Magnesium alloys play an important role in engineering applications, on account of their excellent properties such as high specific strength, high specific stiffness, good castability, excellent machinability, and abundant resources. These properties improve energy efficiency and decrease carbon dioxide emissions as well as other greenhouse gases [1,2]. Among various magnesium alloys, AZ91 alloy (Mg-9 wt.\% Al-1 wt.\% Zn) has superior resistance to corrosion and good mechanical characteristics [3]. It is well established [4] that the solid solubility of $\mathrm{Al}$ in $\alpha-\mathrm{Mg}$ matrix attains its maximum value (12.7 wt.\%) at $437^{\circ} \mathrm{C}$ for the $\mathrm{Mg}$-Al binary system. Zinc is added to this binary system to reduce the high solid solubility of $\mathrm{Al}$ during the aging process. As the $\mathrm{Al} / \mathrm{Zn}$ ratio exceeds $3: 1$, only $\beta-\mathrm{Mg}_{17} \mathrm{Al}_{12}$ phase precipitates. Consequently, corrosion resistance and mechanical properties will be improved [2].

The $\beta-\mathrm{Mg}_{17} \mathrm{Al}_{12}$ phase can be precipitated in the AZ91 alloys continuously or discontinuously. The lamellar structure of discontinuous precipitation (DP) forms along the grain boundaries of $\alpha-\mathrm{Mg}$ [5-10]. The continuous precipitation (CP) occurs in the form of lath-type or fine plate-type morphologies inside $\alpha-\mathrm{Mg}$ grains which have not been occupied by DP [11-14]. At low aging temperatures, DP is favored while $\mathrm{CP}$ invades all samples at high aging temperatures. The continuous, as well as the 
discontinuous precipitates, are formed and controlled by the aging treatment conditions. They can simultaneously or competitively appear at the aging temperatures ranging from 175 to $270{ }^{\circ} \mathrm{C}$ [15-17].

The mechanical characteristics of the as-cast Mg alloys, especially AZ91 alloy, can be improved through the precipitation hardening during the aging treatment process. Several research reports [18-22] have documented the variations in the mechanical characteristics of different $\mathrm{Mg}$-based alloys with the aging treatment. Kim et al. [2] concluded that the changes in the mechanical characteristics during the aging process are associated with the alteration of $\beta-\mathrm{Mg}_{17} \mathrm{Al}_{12}$ precipitation behavior. The effect of precipitation of $\beta-\mathrm{Mg}_{17} \mathrm{Al}_{12}$ phase on the creep behavior of $\mathrm{AZ} 91$ alloy aged at 150 and $200{ }^{\circ} \mathrm{C}$ has also been studied [7]. The results showed that the $\beta-\mathrm{Mg}_{17} \mathrm{Al}_{12}$ phase suffers severe cracking, leading to early failure. Robson and Paa-Rai [18] showed that insoluble $\mathrm{Zn}-\mathrm{Zr}$ particles were present in the microstructure of $\mathrm{Mg}-6 \mathrm{Zn}-0.6 \mathrm{Zr}$ (wt.\%) alloy even after solution heat treatment. Therefore, in $\mathrm{Zn}-\mathrm{Zr}$, particles most likely remained intact after homogenization treatment. Li et al. [19] concluded that the Mg-5Zn-2Gd-0.4Zr (wt.\%) alloy showed a significant age-hardening response with a hardness increment from $62 \mathrm{HV}$ to $72 \mathrm{HV}$ by aging at $200{ }^{\circ} \mathrm{C}$ for up to $80 \mathrm{~h}$. Xia et al. [20] investigated the age-hardening behavior of $\mathrm{Mg}-4 \mathrm{Sm}-\mathrm{xZn}-0.4 \mathrm{Zn}(\mathrm{x}=0,0.3,0.6$, and $1.3 \mathrm{wt} . \%)$ alloy. They reported that all samples exhibited significant precipitation hardening effect. The optimum composition was determined as Mg- $4 \mathrm{Sm}-(0.3-0.6) \mathrm{Zn}-0.4 \mathrm{Zr}$ alloy. Liu et al. [22] studied the microstructure and precipitation behavior of Mg-4Y-2Zn (at.\%) extruded alloy during solution treatment and aging processes. During the aging process, the nanoscale $\beta^{\prime}$ phases were coherent with $\alpha-\mathrm{Mg}$ precipitated in the matrix. Suresh et al. [23] stated that the addition of $0.2 \mathrm{wt} . \%$ charcoal to the AZ91 alloy can significantly refine the microstructure and accelerate the aging kinetics of refined alloys.

An artificial neural network (ANN) model is commonly used for both simulation and prediction of the mechanical properties of metals and alloys. The ANN is inspired by a biological neural network, consisting of interconnected artificial nodes or neurons that can model complicated functional relationships [24]. Okuyucu et al. [25] predicted yield strength, elongation, and tensile strength of aluminum friction stir welding joints at heat affected zone (HAZ) with mean error 0.656, 7.596, and 1.650, respectively, whereas Asadi et al. [26] anticipated the hardness profile and grain size of AZ91/SiC of friction stir processing (FSP) nanocomposite plate with maximum training error $1.8 \%$ and $0.5 \%$, respectively. Yousif et al. [27] established an ANN model for the prediction of tensile stress, bending stress, and elongation of friction stir welding of AA6061 aluminum. The errors of tensile stress, bending stress, and elongation were reported to be $1.7524 \%, 7.3777 \%$, and $11.98 \%$, respectively. Ghetiya et al. [28] used ANN with 4-8-1 architecture to predict the tensile strength of friction stir welding (FSW) joint with less than 3\% error. In their research, Arunchai et al. [29] employed the ANN to model the resistance spot welding (RSW) joints with an accuracy of 95\%. Ansari et al. [24] presented a computational model based on ANN to analyze the friction stir extrusion (FSE) process of magnesium. Multilayer neural network was used to discover the correlation between FSE parameters and average grain size of the produced wires. The accuracy of the developed model can be shown through root mean square error (RMSE) and linear regression analyses. Recently, Habashy et al. [30] applied the ANN for modeling the composite hardness $\left(\mathrm{H}_{\mathrm{c}}\right)$, yield stress $\left(\sigma_{\mathrm{y}}\right)$, and film hardness $\left(\mathrm{H}_{\mathrm{f}}\right)$ of titanium dioxide nanoparticles at different temperatures, dwell times, and relative indentation depths $(\beta)$. Mean squared error values for the prediction of $H_{c}, \sigma_{y}$, and $H_{f}$ were found to be $1.4369 \times 10^{-16}$, $3.9368 \times 10^{-16}$, and $6.807 \times 10^{-18}$, respectively.

The present work intended to investigate the applicability of ANN model to simulate and predict the age-hardening response of AZ91 alloy. The ANN results were compared with the measured experimental data.

\section{Experimental Procedures}

The AZ91 magnesium alloy chemical composition obtained by Magnesium Elektron is listed in Table 1. Block samples with the dimensions $15 \mathrm{~mm} \times 15 \mathrm{~mm} \times 10 \mathrm{~mm}$ of the studied alloy were designed for hardness measurements and microstructure characterization. In order to achieve solution 
annealing, the specimens were exposed to solution heat treatment at a temperature of $420{ }^{\circ} \mathrm{C}$ for $24 \mathrm{~h}$ in a protective argon atmosphere. The annealing furnace (model no. T-5.0x10-w-200, Heraeus type, Germany), power 380 V/50 Hz, 80 Amp was used in the present work. Temperature variations during heat treatment were recorded by a $0.8-\mathrm{mm}$ diameter chromel-alumel (type $\mathrm{K}$ ) thermocoupler, which was connected to a computer-based acquisition system. Later, all samples were dropped into the water at $25{ }^{\circ} \mathrm{C}$ (room temperature) so as to quench and conserve the supersaturated solid solution. Finally, the solution-treated specimens were aged at various temperatures $\left(T_{a}=100,150,200,250\right.$, and $\left.300{ }^{\circ} \mathrm{C}\right)$ for different durations $\left(t_{a}=4,8,12,24,48,96,144\right.$, and $192 \mathrm{~h}$ ) followed by water quenching at $25^{\circ} \mathrm{C}$ in order to study the age-hardening response of AZ91 alloy as shown in Figure 1. The temperature measurement accuracy was $\pm 1{ }^{\circ} \mathrm{C}$.

Table 1. Chemical compositions (wt.\%) of the alloy used in the present study.

\begin{tabular}{ccccccc}
\hline Al & Zn & Mn & Si & Cu & Fe & Mg \\
\hline 8.4 & 0.27 & 0.09 & $<0.02$ & $<0.001$ & $<0.001$ & Bal. \\
\hline
\end{tabular}

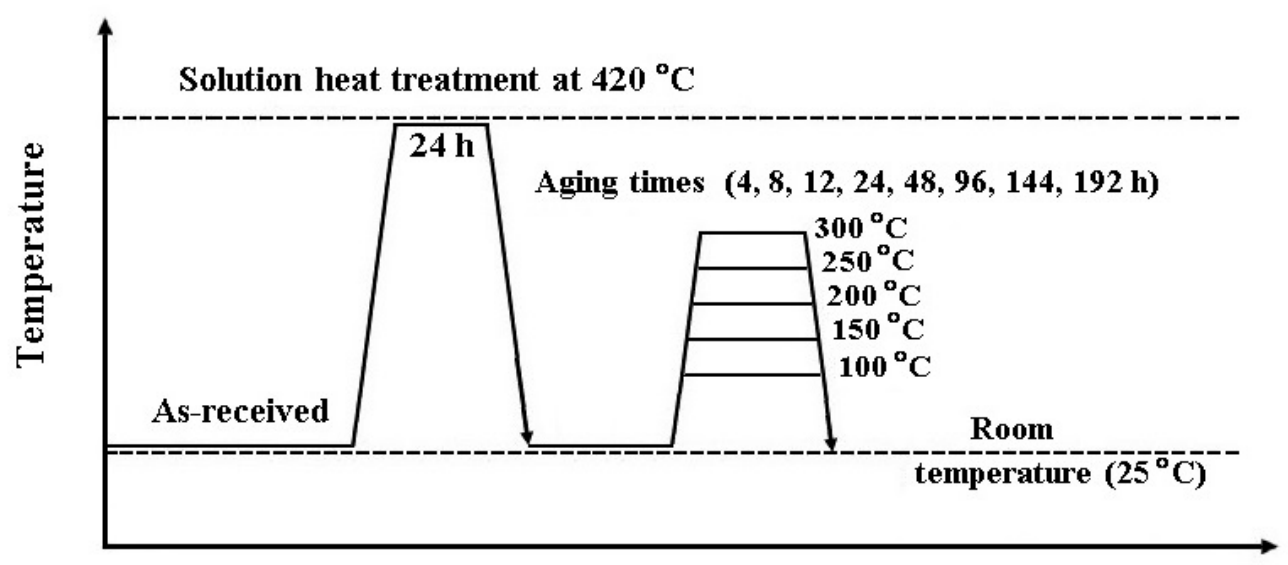

Time

Figure 1. A schematic diagram showing the heat treatment procedure.

To reveal the microstructure of the investigated samples, they were ground and polished according to the usual magnesium alloys' procedures [31]. Then, the prepared specimens were etched for about $90 \mathrm{~s}$ in a nitric acid solution (4 mL HNO3 and $96 \mathrm{~mL} \mathrm{C} 2 \mathrm{H} 5 \mathrm{OH})$. Afterward, the samples were cleaned with anhydrous ethyl alcohol and then dried with air blast. The microstructure examinations were performed on a light microscope Olympus BH2 (Olympus Co., Ltd., Bangkok, Thailand) equipped with a Leica DC 200 MTV-3 camera. A Shimadzu D6000 X-ray diffractometer (Shimadzu Corporation, Tokyo, Japan) with $\mathrm{Cu}-\mathrm{K} \alpha$ radiation operated at $30 \mathrm{kV}$ and $30 \mathrm{~mA}$ (with wavelength $\lambda$ of $0.15406 \mathrm{~nm}$ ) was used to distinguish the formed phases.

The age-hardening response was investigated using a Vickers hardness testing machine under a load of $0.5 \mathrm{~kg}$ for $10 \mathrm{~s}$ at room temperature. To ensure reproducibility, the average of $10 \mathrm{random}$ indentations was taken to calculate each reported hardness value.

\section{Artificial Neural Network (ANN)}

A nonlinear function mapping of the input variables in the corresponding network output variables was provided by the artificial neural network (ANN), and it was not required to have the real mathematics form of the relation between the input and output variables [30]. The most commonly used type of feedforward neural network is multilayer perceptron (MLP). MLP neural network has many layers of simple neurons which are coordinated in a manner that every neuron in a layer is linked to every neuron in the following by weight (see Figure 2). These layers are an input layer, at least one 
hidden layer, and an output layer. The sum of weighted inputs was calculated by all neuron and then converted by the next transfer function:

$$
n_{j}=\frac{1}{1+\exp (-x)}
$$

where $n_{j}$ is the output of the $j$-th neuron, and $x$ is provided with:

$$
x=\sum_{i=1}^{n} w_{i j} p_{i}+b_{j}
$$

where $\mathrm{w}_{\mathrm{ij}}$ is the weights applied from the $\mathrm{i}$-th neurons in the previous layer to the $\mathrm{j}$-th neurons, $\mathrm{p}_{\mathrm{i}}$ is the output from the $i$-th neuron, and $b$ is a bias term.

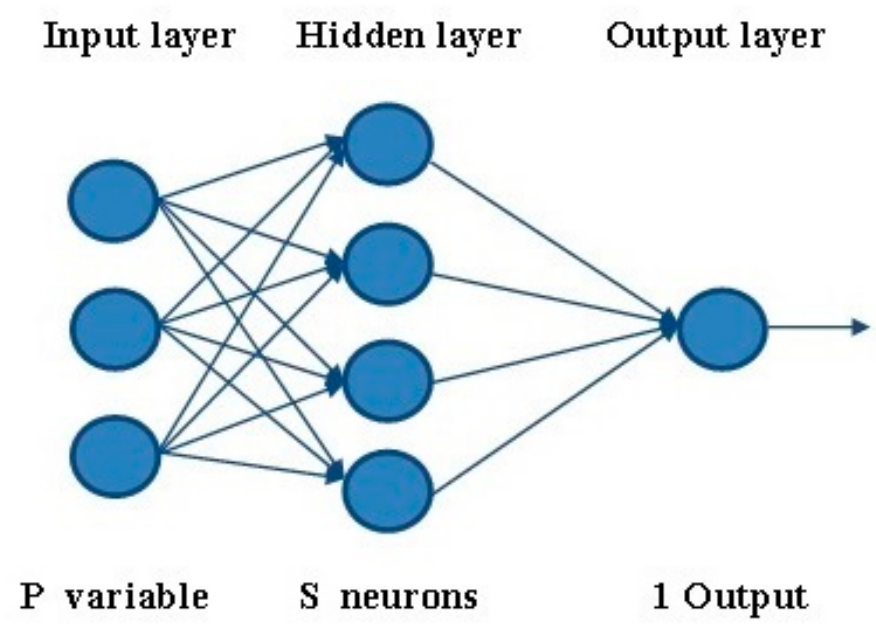

Figure 2. Topology of conventional P-S-1 MLP.

The MLP networks utilize a supervised learning technique. Both back propagation error (BPE) and training data, in the training algorithm, are provided to the networks by the weights adjustment and biases until the expected values for the network are consistent with the actual values. This adjustment is made with the BPE training algorithm by the comparison between the actual value $t_{i j}$ and the expected values $\mathrm{a}_{\mathrm{ij}}$ of the network by calculating the total sum of the square error (SSE) for the $\mathrm{n}$ data of the training dataset,

$$
S S E=\sum_{i=1}^{n}\left(t_{i j}-a_{i j}\right)^{2}
$$

In this study, the ANN model based on multilayer perceptron was used to compute Vickers hardness values. The ANN model was configured to have aging temperatures and aging times as inputs and Vickers hardness values as output, as shown in Figure 3. Various network settings were attempted to provide the best mean square errors (MSE) and the best results using the input-output scheme. The three hidden layers' configuration with different neurons were chosen. In every hidden layer, the number of neurons was 34,24 , and 25 , respectively. The transfer functions were logsig function for all hidden layers and linear pureline function for output layer. 


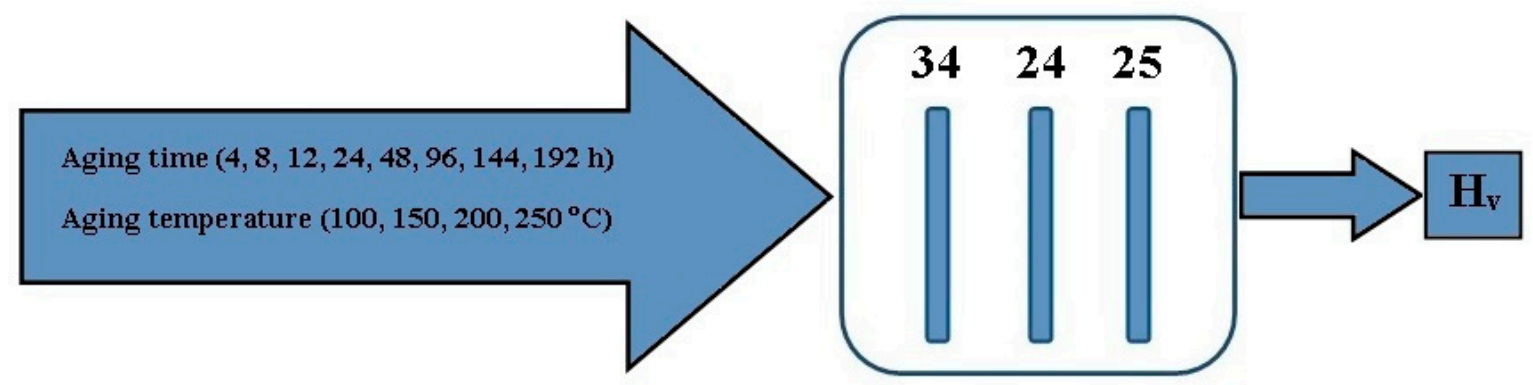

Figure 3. Block diagram of ANN based modeling.

\section{Results and Discussion}

Figure 4 depicted the age-hardening response of AZ91 magnesium alloy at various aging temperatures. The dashed lines interpolate the experimental points represented by the markers. A little augment in the hardness with increasing aging time was detected for specimens aged at $100{ }^{\circ} \mathrm{C}$. The hardness values started to increase considerably when aging at $150{ }^{\circ} \mathrm{C}$ without the attainment of its peak hardness within the examined time interval. After aging at $200^{\circ} \mathrm{C}$, the hardness considerably improved with the extension of aging time, achieving its peak value after 24 hours, and, subsequently, further aging times reduced the hardness values. The same tendency was found at the $250{ }^{\circ} \mathrm{C}$ aging curve as that at $200{ }^{\circ} \mathrm{C}$, but with the lower hardness values. For $250^{\circ} \mathrm{C}$ aging curve, the peak hardness was reached after about $12 \mathrm{~h}$, which was $12 \mathrm{~h}$ earlier than that at $200{ }^{\circ} \mathrm{C}$. This points out that the age-hardening response of AZ91 was accelerated at a higher temperature. No major hardness changes were observed for the AZ91 alloy aged at $300{ }^{\circ} \mathrm{C}$.

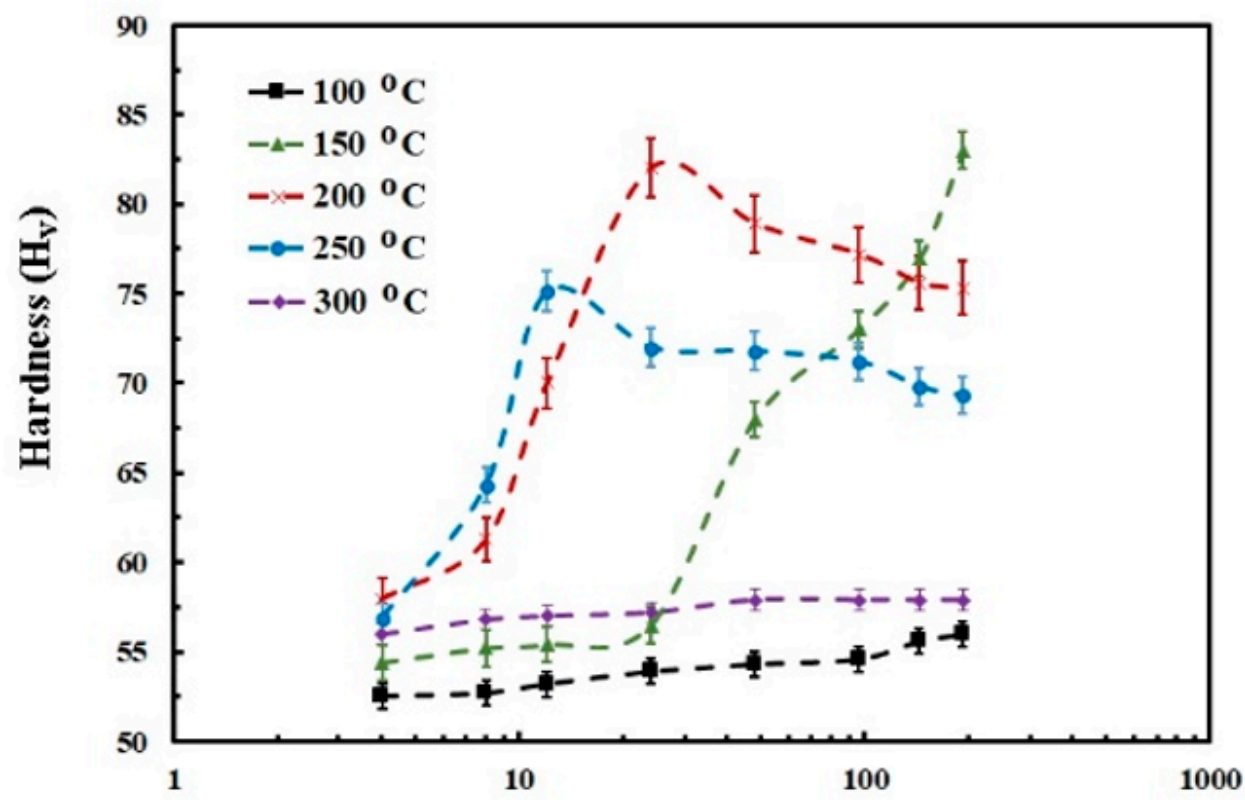

Aging time (h)

Figure 4. Age-hardening curves of AZ91 magnesium alloy aged at different temperatures.

The vital agents that dominate the characteristics of precipitation-hardened alloys are the size, type, distribution, and morphology of the new strengthening precipitates in the original matrix [32]. The variations in the age-hardening curves at various aging temperatures can be ascribed to the interaction between the moving dislocations and $\beta-\mathrm{Mg}_{17} \mathrm{Al}_{12}$ precipitates. At the lower aging temperature of $100{ }^{\circ} \mathrm{C}$, the hardness increased slightly with an increase in aging time from 4 to $192 \mathrm{~h}$. The microstructure of AZ91 samples aged at $100^{\circ} \mathrm{C}$ for 4 and $192 \mathrm{~h}$ are, respectively, shown in 
Figure $5 \mathrm{a}, \mathrm{b}$. The microstructure investigation showed the existence of $\alpha-\mathrm{Mg}$ as a matrix and there was no $\beta-\mathrm{Mg}_{17} \mathrm{Al}_{12}$ phase for sample aged for $4 \mathrm{~h}$ (Figure $5 \mathrm{a}$ ). This may be rendered to that 4 hours were insufficient aging time to produce the DP. With the increment in the aging duration up to $192 \mathrm{~h}$, the discontinuous precipitation colonies of the $\beta\left(\mathrm{Mg}_{17} \mathrm{Al}_{12}\right)$ phase (dark contrast of the second phase) started to form within the primary $\alpha-\mathrm{Mg}$ matrix (light background) (Figure $5 \mathrm{~b}$ ). The existence of a slight volume fraction of the second phase $\left(\beta-\mathrm{Mg}_{17} \mathrm{Al}_{12}\right)$ would lead to a little increase in the hardness.
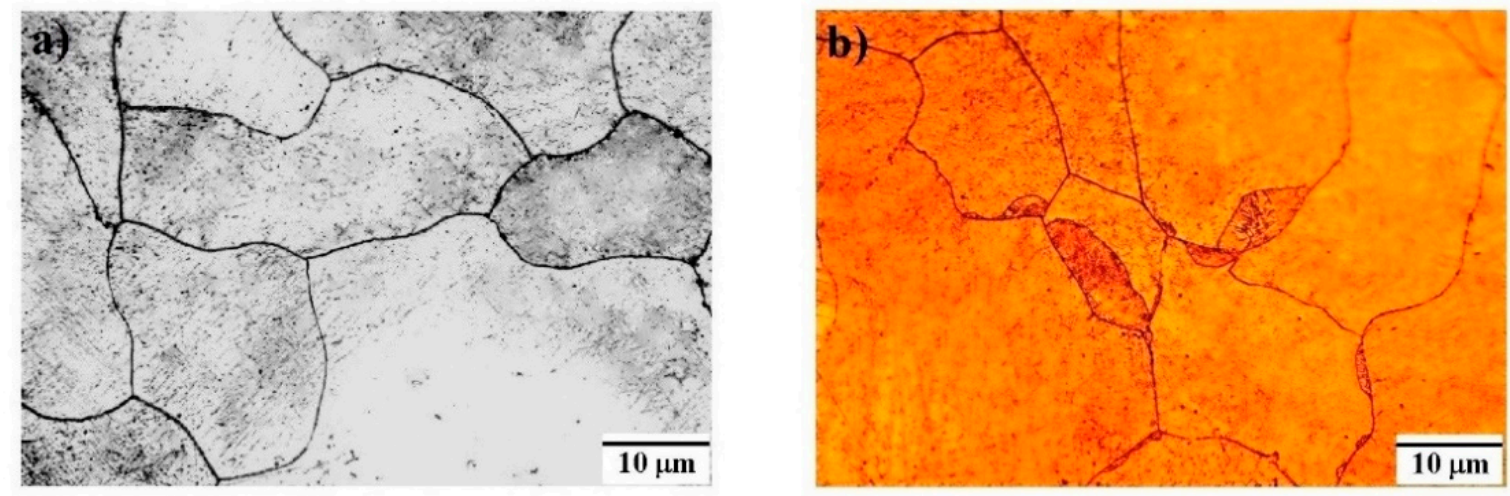

Figure 5. Optical micrographs of AZ91 alloy aged at $100{ }^{\circ} \mathrm{C}$ for (a) $4 \mathrm{~h}$ and (b) $192 \mathrm{~h}$.

When the samples aged at $150^{\circ} \mathrm{C}$, the hardness values improved continuously with the aging time increment. No peak hardness was detected for AZ91 samples aged at $150{ }^{\circ} \mathrm{C}$ even after aging for $192 \mathrm{~h}$. Our results are consistent with those reported by Celotto [33], who found that the peak hardness at $150{ }^{\circ} \mathrm{C}$ reached $100 \mathrm{HV}$ after aging for $10,000 \mathrm{~h}$. Figure $6 \mathrm{a}-\mathrm{d}$ displays typical optical images of samples aged at $150{ }^{\circ} \mathrm{C}$ for $4,24,96$, and $192 \mathrm{~h}$, respectively. It is obviously seen that the microstructure containing the $\beta\left(\mathrm{Mg}_{17} \mathrm{Al}_{12}\right)$ phase existed at the $\alpha$-Mg grain boundaries. By extending aging time, the nucleation sites of DP increased and the previously formed DP continued to expand towards the inside grains and into the adjacent grains as distinguished from the microstructures of samples aged for 24 and $96 \mathrm{~h}$ (Figure $6 \mathrm{~b}, \mathrm{c}$ ). After aging for $192 \mathrm{~h}$, the sample was invaded by the DP (Figure 6d). It has been reported [34] that the $\beta\left(\mathrm{Mg}_{17} \mathrm{Al}_{12}\right)$ phase nucleated at the grain boundaries then developed as the grain boundaries, migrating towards the adjacent grains. The depletion of $\mathrm{Al}$ solute atoms behind grain boundaries should associate this migration. Zheng et al. [35] indicated that the migration of the grain boundary would enhance the nucleation and growth of DP. Therefore, the grain boundary migration performed a significant role in the nucleation and growth of DP [36]. Figure 6 confirms that the volume fraction of DPs increased with the aging time, resulting in higher hardness values (Figure 4).

Figure 7 exhibits typical optical images of samples aged at $200{ }^{\circ} \mathrm{C}$ for different times. After the aging treatment for $4 \mathrm{~h}$, it was detected the lamellar structure of the DPs distributed along the grain boundaries of the $\alpha-\mathrm{Mg}$ matrix (Figure 7a). The microstructure evolution showed that the whole sample had been invaded by the DP as the aging time increased from 4 to 24 hours (Figure $7 \mathrm{~b}$ ). However, when the sample aged for 24 hours, the maximum hardness value was achieved. The DPs that acted as an impediment to dislocation motion led to a maximum hardness value. The reduction in the hardness values with the aging period interval (24-92 h) might be attributed to the existence of both CPs and DPs (Figure $7 \mathrm{c}$ ). It has been stated $[37,38]$ that the growth rate of discontinuous precipitates would terminate if the grains were filled with the DPs or if CPs began to grow considerably and hinder the propagation of the discontinuous precipitates. Thus, the volume fraction of continuous precipitates grew as the aging time increased from 24 to $96 \mathrm{~h}$, and that of discontinuous precipitation gradually reduced, resulting in lower hardness values. Earlier studies $[39,40]$ declared that discontinuous precipitates were effectively inhibited as the continuous precipitates were formed. Dissimilar to the microstructure of the sample aged for $92 \mathrm{~h}$ (Figure 7c), plenty of lath-shaped precipitates occupied the whole sample, and no discontinuous precipitates were detected (Figure 7d). Since the CPs consisting of coarsely 
lath-shaped precipitates lie on the base plane of matrix, there are great opportunities for dislocations to bypass the obstacles leading to lower hardness values. Comparing the micrographs shown in Figures 7 and 8 , it is clear that the microstructure is identical, while the volume fraction of $\beta$-phase differs. The samples aged at $200{ }^{\circ} \mathrm{C}$ had volume fraction of $\beta$-phase that was considerably denser than that of the $250{ }^{\circ} \mathrm{C}$ samples, which could explain the higher hardness values for samples aged at $200{ }^{\circ} \mathrm{C}$. The hardness response for all the AZ91 samples aged at $300{ }^{\circ} \mathrm{C}$ for various times (4-192 h) was nearly constant, and it was found to be lower than that of the samples aged at $250{ }^{\circ} \mathrm{C}$. The low hardness response for aging at $300^{\circ} \mathrm{C}$ may be rendered to the formation, growth, and coarsening of CPs. The CPs of the small number and large size were less effective to prevent the dislocations' motion. This trend would lead to a loss of hardness. The CPs' precipitating during aging at $300{ }^{\circ} \mathrm{C}$ in the present work agrees with the previous results of AZ91 alloy investigations [8,33,41].
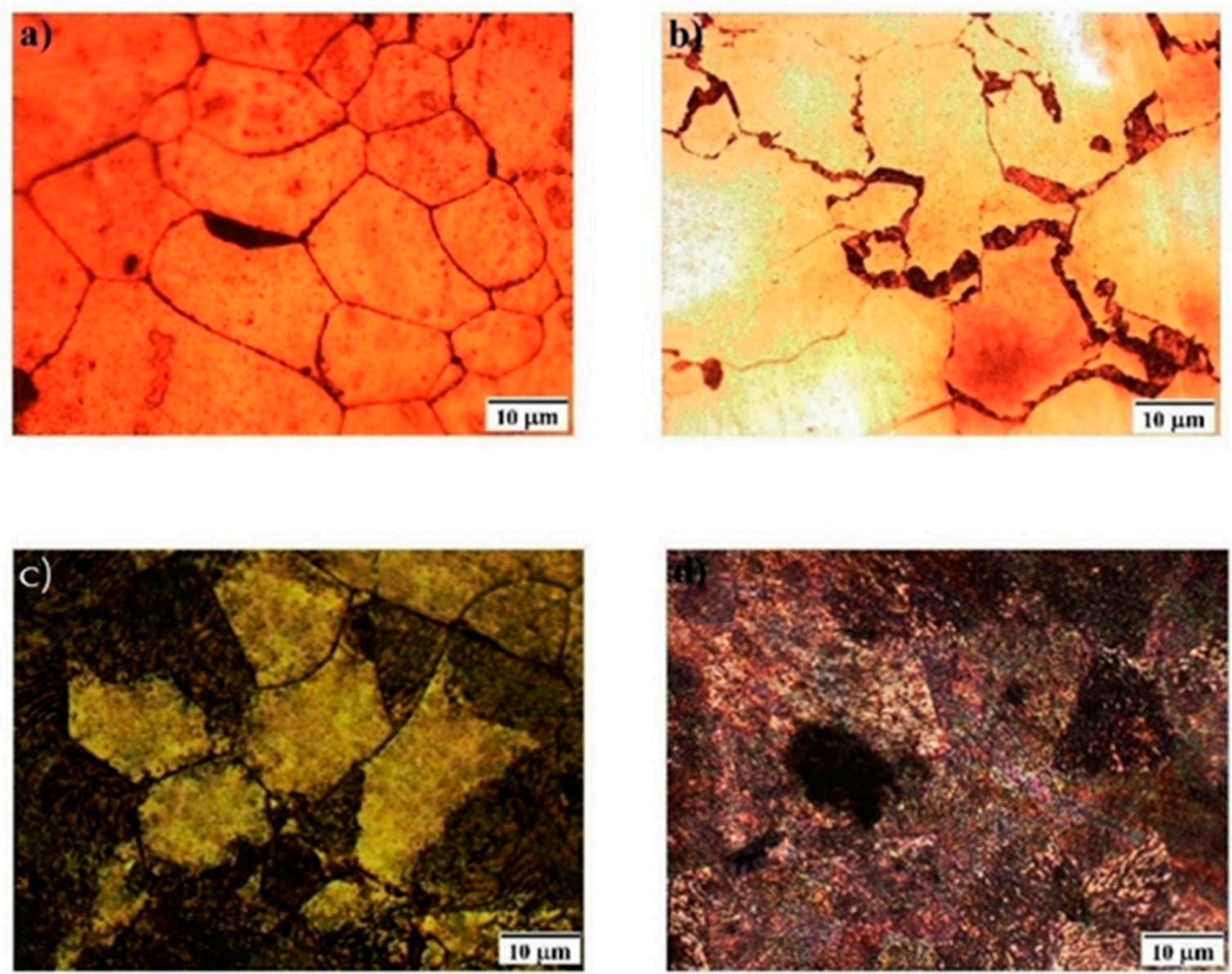

Figure 6. Optical micrographs of AZ91 alloy aged at $150^{\circ} \mathrm{C}$ for (a) $4 \mathrm{~h}$, (b) $24 \mathrm{~h}$, (c) $96 \mathrm{~h}$, and (d) $192 \mathrm{~h}$.
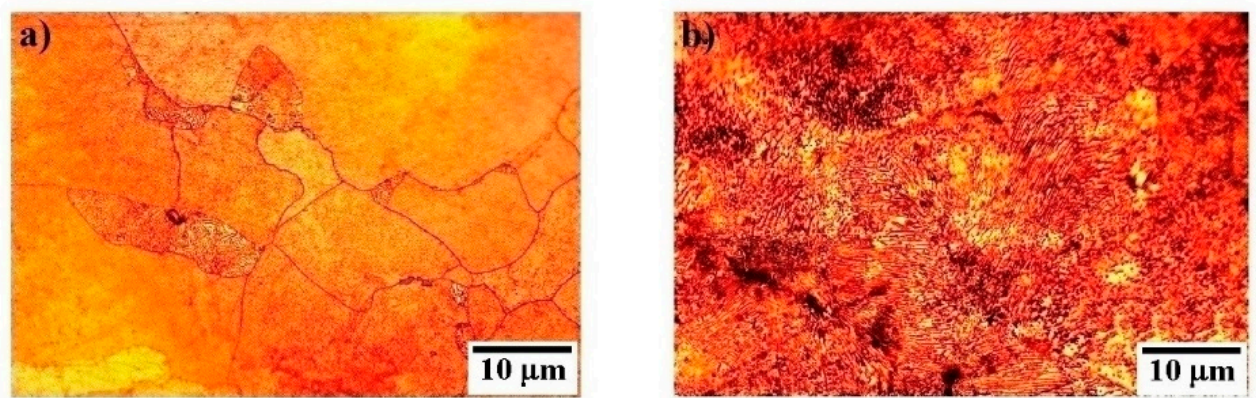

Figure 7. Cont. 

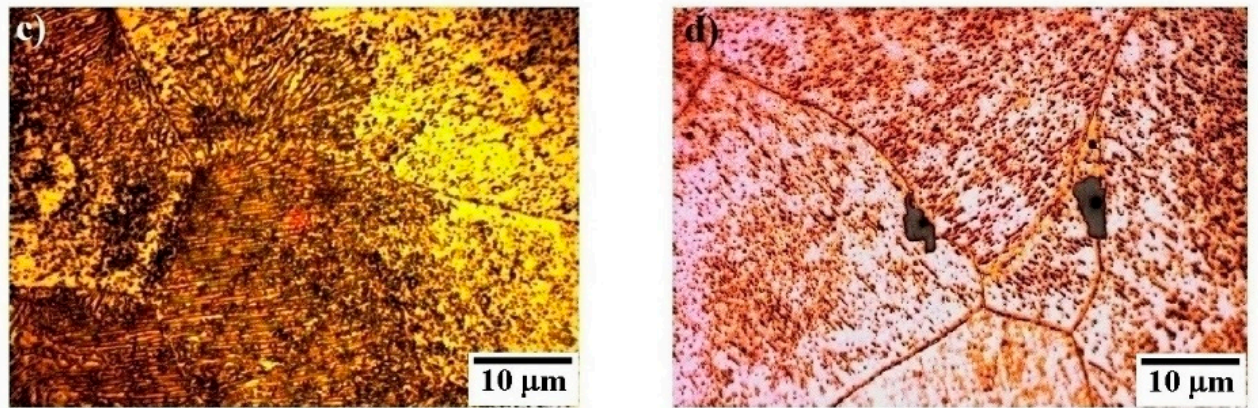

Figure 7. Optical micrographs of AZ91 alloy aged at $200^{\circ} \mathrm{C}$ for (a) 4 h, (b) 24 h, (c) 96 h, and (d) $192 \mathrm{~h}$.
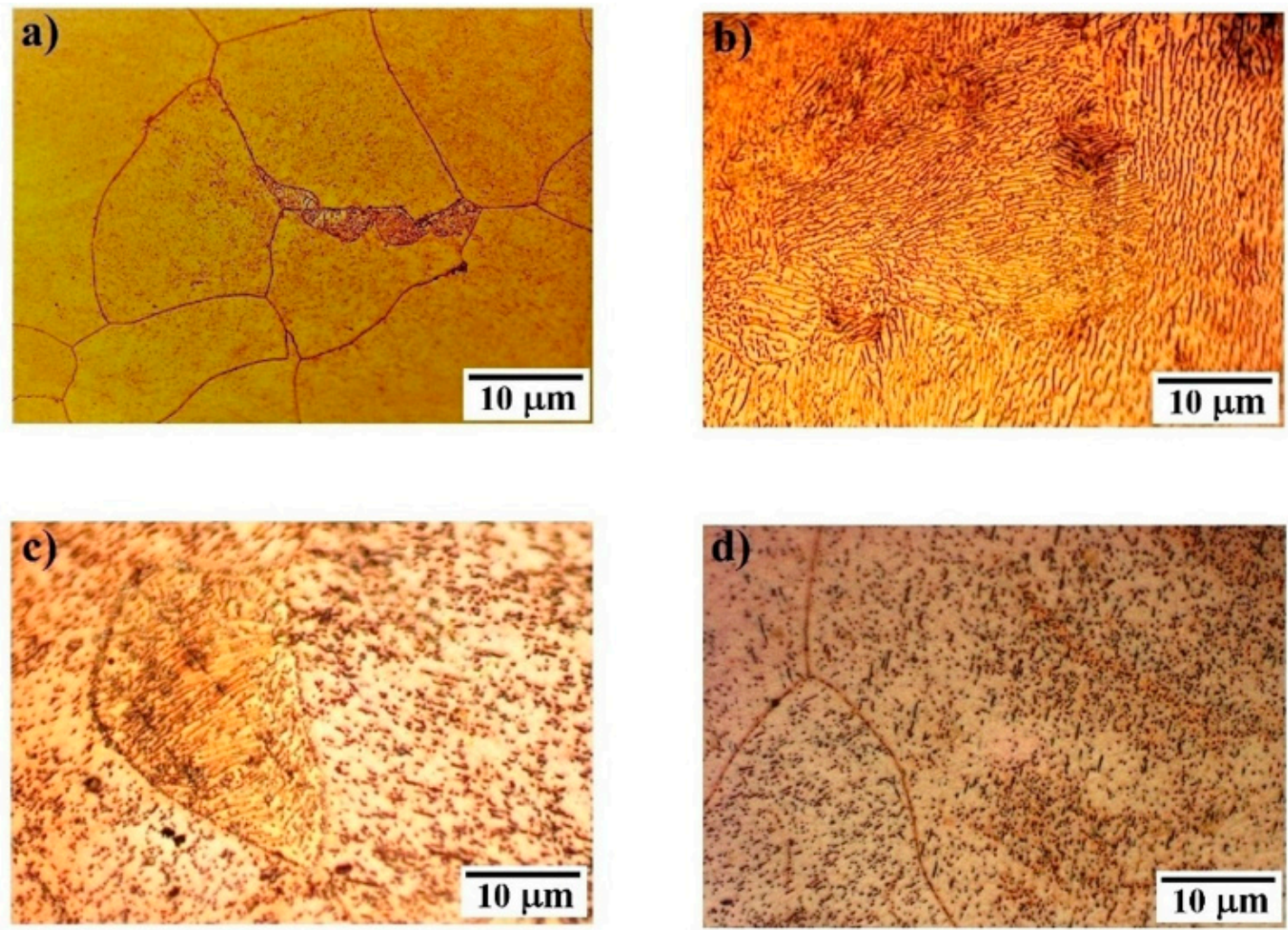

Figure 8. Optical micrographs of AZ91 alloy aged at $250{ }^{\circ} \mathrm{C}$ for (a) $4 \mathrm{~h},(\mathbf{b}) 12 \mathrm{~h}$, (c) $96 \mathrm{~h}$, and (d) $192 \mathrm{~h}$.

X-ray diffraction (XRD) measurements were applied for the studied samples aged at different temperatures for various aging durations. The recorded XRD series for all the investigated samples included both $\alpha$-Mg with hcp crystal structure according to JCPDS card no. 65-3365 and body-centered cubic crystal structured ( $\beta-\mathrm{Mg}_{17} \mathrm{Al}_{12}$ phase) according to JCPDS card no. 73-1148. The crystalline lattice parameters $a, c$, and $c / a$ ratio were calculated for $\alpha$-Mg matrix at different aging temperatures and indexed with errors in Table 2 by the aid of X-ray data. The errors were calculated for $a, c$, and $c / a$ ratio with respect to their standard values recorded in JCPDS card no. $65-3365$ for $\alpha-\mathrm{Mg}$ phase $(a=3.208 \AA, c=5.21 \AA$, and $c / a=1.62406)$. For $\alpha-\mathrm{Mg}$ phase of hcp crystal structure, the interplanar distance, $d$, between these two planes (100) and (101) can be correlated to $a$ and $c$ lattice parameters through the following equation:

$$
\frac{1}{d^{2}}=\frac{4}{3}\left(\frac{h^{2}+h k+k^{2}}{a^{2}}\right)+\frac{l^{2}}{c^{2}}
$$


Table 2. The calculated crystalline lattice parameters $a, c$, and $c / a$ ratio for $\alpha$-Mg matrix at different aging temperatures and various aging times.

\begin{tabular}{|c|c|c|c|c|c|c|c|c|c|c|c|}
\hline \multirow[b]{2}{*}{$\begin{array}{c}\text { Lattice } \\
\text { Parameter }\end{array}$} & \multirow[b]{2}{*}{$\begin{array}{c}\text { Aging } \\
\text { Time (h) }\end{array}$} & \multicolumn{10}{|c|}{ Aging Temperature $\left({ }^{\circ} \mathrm{C}\right)$} \\
\hline & & 100 & $\begin{array}{c}\text { Error } \\
\%\end{array}$ & 150 & $\begin{array}{c}\text { Error } \\
\%\end{array}$ & 200 & $\begin{array}{c}\text { Error } \\
\%\end{array}$ & 250 & $\begin{array}{c}\text { Error } \\
\%\end{array}$ & 300 & $\begin{array}{c}\text { Error } \\
\%\end{array}$ \\
\hline \multirow{8}{*}{$a(\AA)$} & 4 & 3.175 & 1.03 & 3.179 & 0.9 & 3.194 & 0.43 & 3.19 & 0.56 & 3.183 & 0.79 \\
\hline & 8 & 3.176 & 0.99 & 3.18 & 0.87 & 3.197 & 0.34 & 3.2 & 0.25 & 3.184 & 0.75 \\
\hline & 12 & 3.177 & 0.96 & 3.181 & 0.85 & 3.21 & 0.06 & 3.23 & 0.69 & 3.185 & 0.72 \\
\hline & 24 & 3.179 & 0.9 & 3.183 & 0.78 & 3.24 & 0.99 & 3.216 & 0.24 & 3.186 & 0.69 \\
\hline & 48 & 3.181 & 0.84 & 3.204 & 0.12 & 3.227 & 0.58 & 3.21 & 0.062 & 3.187 & 0.65 \\
\hline & 96 & 3.182 & 0.81 & 3.212 & 0.125 & 3.22 & 0.37 & 3.207 & 0.0312 & 3.188 & 0.62 \\
\hline & 144 & 3.183 & 0.78 & 3.224 & 0.499 & 3.22 & 0.37 & 3.205 & 0.0935 & 3.188 & 0.62 \\
\hline & 192 & 3.184 & 0.75 & 3.229 & 0.655 & 3.22 & 0.37 & 3.205 & 0.0935 & 3.188 & 0.62 \\
\hline \multirow{8}{*}{$c(\AA)$} & 4 & 5.213 & 0.058 & 5.21 & 0 & 5.19 & 0.384 & 5.21 & 0.192 & 5.213 & 0.115 \\
\hline & 8 & 5.211 & 0.019 & 5.205 & 0.084 & 5.1736 & 0.699 & 5.206 & 0.787 & 5.211 & 0.134 \\
\hline & 12 & 5.21 & 0 & 5.206 & 0.077 & 5.17 & 0.768 & 5.206 & 0.576 & 5.21 & 0.154 \\
\hline & 24 & 5.209 & 0.019 & 5.202 & 0.077 & 5.185 & 0.479 & 5.202 & 0.465 & 5.209 & 0.249 \\
\hline & 48 & 5.208 & 0.038 & 5.198 & 0.154 & 5.196 & 0.269 & 5.198 & 0.384 & 5.208 & 0.269 \\
\hline & 96 & 5.207 & 0.058 & 5.179 & 0.595 & 5.177 & 0.633 & 5.179 & 0.578 & 5.207 & 0.288 \\
\hline & 144 & 5.206 & 0.077 & 5.168 & 0.806 & 5.17 & 0.768 & 5.168 & 0.595 & 5.206 & 0.326 \\
\hline & 192 & 5.205 & 0.096 & 5.158 & 0.998 & 5.168 & 0.806 & 5.158 & 0.614 & 5.205 & 0.326 \\
\hline \multirow{8}{*}{$c / a$} & 4 & 1.642 & 1.098 & 1.639 & 0.912 & 1.625 & 0.053 & 1.630 & 0.371 & 1.635 & 0.683 \\
\hline & 8 & 1.641 & 1.027 & 1.637 & 0.796 & 1.618 & 0.357 & 1.615 & 0.539 & 1.634 & 0.618 \\
\hline & 12 & 1.640 & 0.976 & 1.636 & 0.778 & 1.611 & 0.829 & 1.604 & 1.253 & 1.633 & 0.567 \\
\hline & 24 & 1.639 & 0.893 & 1.634 & 0.631 & 1.600 & 1.463 & 1.613 & 0.703 & 1.631 & 0.439 \\
\hline & 48 & 1.637 & 0.81 & 1.622 & 0.106 & 1.610 & 0.853 & 1.617 & 0.446 & 1.630 & 0.388 \\
\hline & 96 & 1.636 & 0.759 & 1.612 & 0.719 & 1.608 & 1.004 & 1.6151 & 0.547 & 1.629 & 0.338 \\
\hline & 144 & 1.635 & 0.708 & 1.603 & 1.298 & 1.606 & 1.138 & 1.616 & 0.502 & 1.628 & 0.299 \\
\hline & 192 & 1.634 & 0.657 & 1.597 & 1.642 & 1.605 & 1.176 & 1.6156 & 0.521 & 1.628 & 0.299 \\
\hline
\end{tabular}

Figure 9a illustrates the variation of $a$ with aging time for all the investigated samples aged at various temperatures. The lines joining the markers are guides for the eye. It is clearly seen that the trend of the lattice parameter, $a$, was in contrary to the behavior of the $c / a$ ratio (Figure $9 \mathrm{c}$ ) for the samples aged at 150,200 , and $250^{\circ} \mathrm{C}$. On the other hand, their values were approximately constant with the variation of the aging time at 100 and $300^{\circ} \mathrm{C}$. It is observed from Figure $9 \mathrm{a}$, the crystalline lattice parameter, $a$, increased continuously with aging time at $150^{\circ} \mathrm{C}$. The values of $a$ varied from $3.179 \AA$ to $3.229 \AA$ at the maximum aging time of $192 \mathrm{~h}$. This variation equaled about $1.57 \%$ from its initial value at the minimum aging time of $4 \mathrm{~h}$. At the aging temperature of $200^{\circ} \mathrm{C}$, the $a$ values increased with increasing aging time up to $24 \mathrm{~h}$, and then they decreased and remained constant. A similar trend was observed for the lattice parameter, $a$, at $250^{\circ} \mathrm{C}$ but the reduction occurred after the lower aging time of $12 \mathrm{~h}$. Figure $9 \mathrm{~b}$ clarifies the variations of the lattice parameter, $c$, with aging time at different aging temperatures. From this figure, it is obviously seen that the parameter $c$ had a value of about $5.211 \AA$, and still remained constant at $100^{\circ} \mathrm{C}$. Moreover, it had a value of about $5.204 \AA$ at $300{ }^{\circ} \mathrm{C}$. The lattice parameter, $c$, showed the same behavior of $c / a$ ratio with aging time and temperature. These calculated values of $a$ and $c$ are matched with recorded values in JCPDS card no. 65-3365 for Mg matrix, and they agreed well with the values reported in the literature [39,41]. The separation of aluminum to form $\beta-\mathrm{Mg}_{17} \mathrm{Al}_{12}$ phase may be held responsible for the alteration in the lattice parameter values. Moreover, the precipitation mechanism was improved at $200^{\circ} \mathrm{C}$, which strongly affected the hardness values of the investigated alloy. 

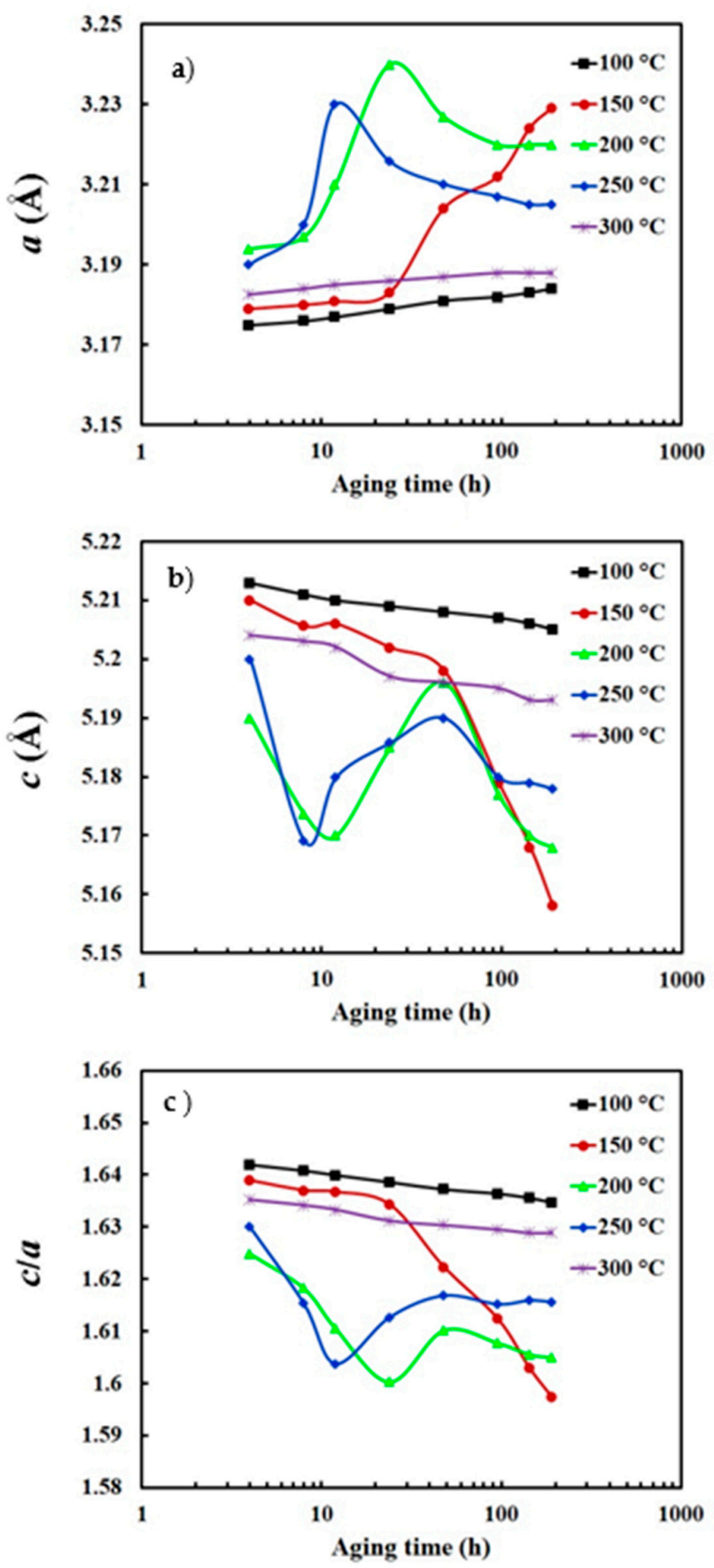

Figure 9. The variation of (a) the lattice parameter $a,(\mathbf{b})$ the lattice parameter $c$, and (c) $c / a$ ratio with the aging time for all the investigated samples aged at different temperatures.

The ANN model was used to simulate and predict the Vickers hardness of AZ91 magnesium alloy. Two inputs parameters, aging time $\left(t_{a}\right)$ and aging temperature $\left(T_{a}\right)$, were taken into account to simulate the Vickers hardness as an output parameter. The data were taken from the experimental results. The transfer function was selected as a logsig and pureline for hidden layers and output layer, respectively. Experimental data were used for training the model. The ANN was trained with measured datasets at $100,150,200$, and $250{ }^{\circ} \mathrm{C}$. The training was carried out for 541 iterations (epochs). The artificial neural 
network was endeavoring to get a better mean square error (MSE) and best execution for the network. The goal of the training was $10^{-5}\left(\mathrm{MSE}=10^{-5}\right.$ ) and we reached the nearest value (best) to this goal.

The result of training is shown in Figure 10. It is clearly seen that the mean squared error of the network decreased from a large value to a smaller value. Moreover, the network was learning. After the network memorized the training set, training was completed. The obtained equation (which represents the hardness, $\mathrm{H}_{\mathrm{V}}$ ) for network is represented in Appendix A. The best ANN model training was obtained according to the value of MSE $\left(9.8256 \times 10^{-6}\right)$ which represented the difference between simulation results and experimental data. The performance of the ANN model was validated by comparing the prediction values at $300{ }^{\circ} \mathrm{C}$ with the measured experimental data. The predicted values were in good agreement with the measured dataset at $300^{\circ} \mathrm{C}$. Results of simulation, prediction, and experimental values are shown in Figure 11. The age-hardening response was simulated at temperatures of $100,150,200$, and $250^{\circ} \mathrm{C}$ and predicted at temperature of $300^{\circ} \mathrm{C}$. Figure 11 depicts that the simulation and prediction results of the ANN were in good agreement with experimental data of the age-hardening response of the investigated alloy. Comparison between the ANN results and experimental data is depicted in Table 3. In summary, the present study showed that the ANN model can effectively simulate and predict the age-hardening response of AZ91 magnesium alloy.

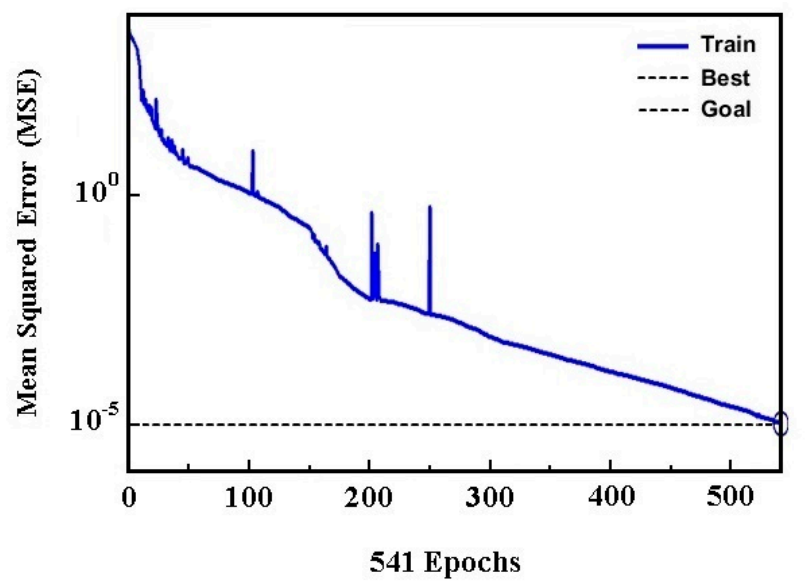

Figure 10. The ANN performance for hardness profile of AZ91 alloy.

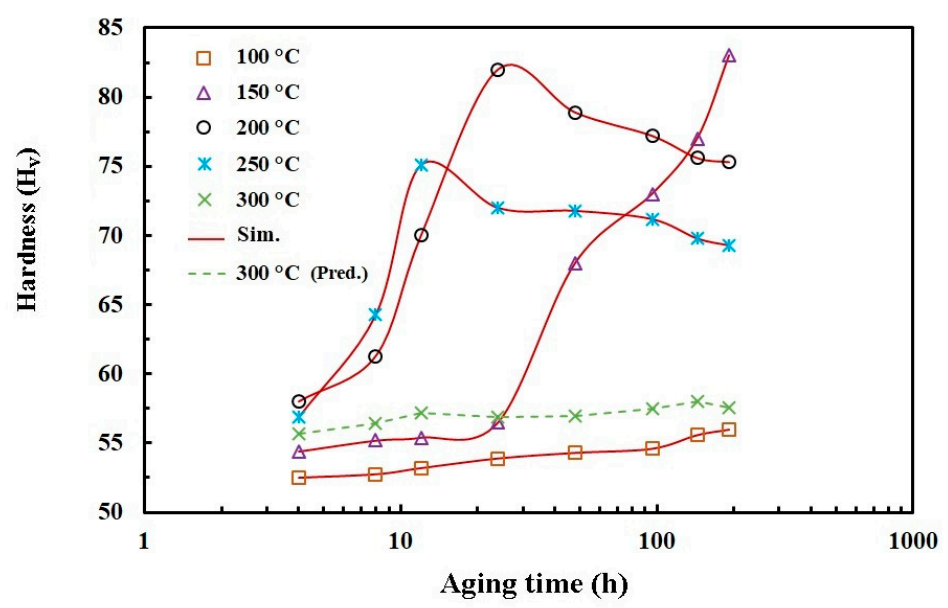

Figure 11. Simulation and prediction of the hardness profile based ANN model. 
Table 3. Comparison between the ANN results and experimental data.

\begin{tabular}{ccccccccccc}
\hline \multicolumn{10}{c}{} & \multicolumn{10}{c}{ Aging Temperature $\left.\mathbf{(}^{\circ} \mathbf{C}\right)$} \\
\hline Aging & \multicolumn{2}{c}{$\mathbf{1 0 0}$} & \multicolumn{2}{c}{$\mathbf{1 5 0}$} & \multicolumn{2}{c}{$\mathbf{2 0 0}$} & \multicolumn{2}{c}{$\mathbf{2 5 0}$} & \multicolumn{3}{c}{$\mathbf{3 0 0}$} \\
Time (h) & Exp. & Sim. & Exp. & Sim. & Exp. & Sim. & Exp. & Sim. & Exp. & Pred. \\
\hline 4 & 52.50 & 52.48 & 54.40 & 54.40 & 58.00 & 58.00 & 56.90 & 56.88 & 56.00 & 55.70 \\
8 & 52.70 & 52.74 & 55.21 & 55.19 & 61.21 & 61.30 & 64.30 & 64.25 & 56.80 & 56.40 \\
12 & 53.20 & 53.18 & 55.40 & 55.40 & 70.00 & 70.00 & 75.12 & 75.10 & 57.00 & 57.15 \\
24 & 53.89 & 53.89 & 56.50 & 56.50 & 82.00 & 81.95 & 72.00 & 72.00 & 57.20 & 56.86 \\
48 & 54.30 & 54.29 & 68.11 & 68.00 & 78.90 & 78.89 & 71.80 & 71.80 & 57.90 & 56.93 \\
96 & 54.60 & 54.60 & 73.00 & 73.00 & 77.23 & 77.20 & 71.25 & 71.21 & 57.90 & 57.50 \\
144 & 55.60 & 55.59 & 77.00 & 76.90 & 75.58 & 75.60 & 69.80 & 69.80 & 57.90 & 58.01 \\
192 & 56.00 & 56.00 & 83.00 & 82.90 & 75.33 & 75.30 & 69.30 & 69.30 & 57.90 & 57.56 \\
\hline
\end{tabular}

\section{Conclusions}

In this article, the artificial neural network (ANN) model was adopted to simulate and predict the hardness profiles of AZ91 magnesium alloy. The results of ANN were compared with the experimental data and the following conclusions could be drawn from this study:

(1) The microstructure evolutions revealed that the mode of precipitation in AZ91 alloy was strongly affected by aging temperature and time of aging. The discontinuous precipitation was favored at low temperatures of aging $\left(100\right.$ and $\left.150^{\circ} \mathrm{C}\right)$, while at high aging temperature $\left(300^{\circ} \mathrm{C}\right)$, continuous precipitation $(\mathrm{CP})$ invaded all the samples. Both discontinuous and continuous precipitation reactions occurred at the intermediate aging temperature range $\left(200-250^{\circ} \mathrm{C}\right)$.

(2) The variations in the age-hardening response of AZ91 alloy at various aging temperatures was clarified in view of the size, morphology, and distribution of the $\beta-\mathrm{Mg}_{17} \mathrm{Al}_{12}$ precipitates.

(3) Based on the artificial neural network (ANN) model, simulated analysis showed a high correspondence with very low mean square error (MSE). The simulation results indicated higher precision of the operating model to the experimental data.

(4) The prediction results of the ANN model were found to be in good agreement with the measured dataset.

(5) The ANN model effectively simulated and predicted the age-hardening response of AZ91 magnesium alloy.

Author Contributions: Conceptualization, A.F.A.E.-R., H.Y.Z., and D.M.H.; investigation, A.F.A.E.-R., H.Y.Z., and H.M.A.-M.; methodology, A.F.A.E.-R., H.Y.Z., D.M.H., and H.M.A.-M.; writing-original draft, D.M.H. and H.M.A.-M.; writing-review and editing, A.F.A.E.-R. and H.Y.Z. All authors have read and agreed to the published version of the manuscript.

Funding: This research was funded by King Khalid University through General Research Project under grant number G.R.P/259/40.

Acknowledgments: The authors extend their appreciation to the Deanship of Scientific Research at King Khalid University for funding this work through General Research Project under grant number G.R.P/259/40.

Conflicts of Interest: The authors declare no conflict of interest.

\section{Appendix A}

The equation which describes hardness is given by:

$\mathrm{H}=$ pure line $[$ net.LW $\{4,3\} \operatorname{logsig}$ (net.LW $\{3,2\} \operatorname{logsig}$ (net.LW $\{2,1\} \operatorname{logsig}$ (net.IW $\{1,1\} \mathrm{T}+$ net.b $\{1\})+$ net.b $\{2\})+$ net.b $\{3\}+$ net.b $\{4\}]$ 


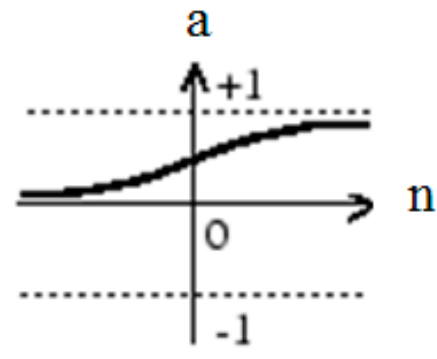

$\mathrm{a}=\log \operatorname{sig}(\mathrm{n})$

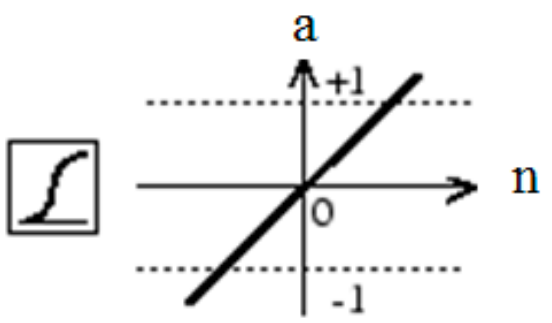

$\mathrm{a}=$ pureline $(\mathrm{n})$

Where $\mathrm{T}$ is the inputs ( temperatures and times), net.IW $\{1,1\}$ is linked weights between the input layer and first hidden layer, net.LW $\{2,1\}$ is linked weights between first and second hidden layer, net.LW $\{3,2\}$ is linked weights between the second and third layer, net.LW $\{4,3\}$ is linked weights between the third and output layer, net.b $\{1\}$ is the bias of the first hidden layer, net.b $\{2\}$ is the bias of the second hidden layer, net.b $\{3\}$ is the bias of the third layer, and net.b $\{4\}$ is the bias of the output layer.

\section{References}

1. Xiao, P.; Gao, Y.; Yang, X.; Xu, F.; Yang, C.; Li, B.; Li, Y.; Liu, Z.; Zheng, Q. Processing, microstructure and ageing behavior of in-situ submicronTiB2 particles reinforced AZ91 Mg matrix composites. J. Alloys Compd. 2018, 764, 96-106. [CrossRef]

2. Kim, S.H.; Lee, J.U.; Kim, Y.J.; Bae, J.H.; You, B.S.; Park, S.H. Accelerated precipitation behavior of cast Mg-Al-Zn alloy by grain refinement. J. Mater. Sci. Technol. 2018, 34, 265-276. [CrossRef]

3. Abd El-Rehim, A.F.; Zahran, H.Y.; Al-Masoud, H.M.; Habashy, D.M. Microhardness and microstructure characteristics of AZ91magnesium alloy under different cooling rate conditions. Mater. Res. Express 2019, 6, 086572. [CrossRef]

4. Nie, J.F. Precipitation and hardening in magnesium alloys. Metall. Mater. Trans. A 2012, 43, 3891-3939. [CrossRef]

5. Lee, J.U.; Kim, S.H.; Kim, Y.J.; Park, S.H. Effects of homogenization time on aging behavior and mechanical properties of AZ91 alloy. Mater. Sci. Eng. A 2018, 714, 49-58. [CrossRef]

6. Jun, J.H. Dependence of hardness on interlamellar spacing of discontinuous precipitates in cast AZ91 magnesium alloy. J. Alloys Compd. 2017, 725, 237-241. [CrossRef]

7. Srinivasan, A.; Ajithkumar, K.K.; Swaminathan, J.; Pillai, U.T.S.; Pai, B.C. Creep behavior of AZ91 magnesium alloy. Procedia Eng. 2013, 55, 109-113. [CrossRef]

8. Braszczynska-Malik, K.N. Discontinuous and continuous precipitation in magnesium-aluminium type alloys. J. Alloys Compd. 2009, 477, 870-876. [CrossRef]

9. Yu, S.; Gao, Y.; Liu, C.; Han, X. Effect of aging temperature on precipitation behavior and mechanical properties of extruded AZ80-Ag alloy. J. Alloys Compd. 2015, 646, 431-436. [CrossRef]

10. Lai, W.J.; Li, Y.Y.; Hsu, Y.F.; Trong, S.; Wang, W.H. Aging behaviour and precipitate morphologies in Mg-7.7Al-0.5Zn-0.3Mn (wt.\%) alloy. J. Alloys Compd. 2009, 476, 118-124. [CrossRef]

11. Zhou, J.P.; Zhao, D.S.; Wang, R.H.; Sun, Z.F.; Wang, J.B.; Gui, J.N.; Zheng, O. In Situ observation of ageing process and new morphologies of continuous precipitates in AZ91 magnesium alloy. Mater. Lett. 2007, 61, 4707-4710. [CrossRef]

12. Zhang, M.X.; Kelly, P.M. Crystallography of $\mathrm{Mg}_{17} \mathrm{Al}_{12}$ precipitates in AZ91D alloy. Scripta Materialia 2003, 48, 647-652. [CrossRef]

13. Duly, D.; Simon, J.P.; Brechet, Y. On the competition between continuous and discontinuous precipitations in binary Mg-Al alloys. Acta Metallurgica Materialia 1995, 43, 101-106.

14. Sahoo, B.N.; Panigrahi, S.K. Effect of In Situ (TiC-TiB2) reinforcement on aging and mechanical behavior of AZ91 magnesium matrix composite. Mater. Charact. 2018, 139, 221-232. [CrossRef]

15. Celotto, S.; Bastow, T.J. Study of precipitation in aged binary $\mathrm{Mg}-\mathrm{Al}$ and ternary $\mathrm{Mg}-\mathrm{Al}-\mathrm{Zn}$ alloys using 27Al NMR spectroscopy. Acta Materialia 2001, 49, 41-51. [CrossRef]

16. Bastow, T.J.; Celotto, S. Clustering and formation of nano-precipitates in dilute aluminium and magnesium alloys. Mater. Sci. Eng. C 2003, 23, 757-762. [CrossRef] 
17. Xiuqing, Z.; Lihua, L.; Naiheng, M.; Haowei, W. Effect of aging hardening on In Situ synthesis magnesium matrix composites. Mater. Chem. Phys. 2006, 96, 9-15. [CrossRef]

18. Robson, J.D.; Paa-Rai, C. The interaction of grain refinement and ageing in magnesium-zinc-zirconium (ZK) alloys. Acta Materialia 2015, 95, 10-19. [CrossRef]

19. Li, J.H.; Barrirero, J.; Sha, G.; Aboulfadl, H.; Mücklich, F.; Schumacher, P. Precipitation hardening of an Mg-5Zn-2Gd-0.4Zr (wt.\%) alloy. Acta Materialia 2016, 108, 207-218. [CrossRef]

20. Xia, X.; Sun, W.; Luo, A.A.; Stone, D.S. Precipitation evolution and hardening in Mg-Sm-Zn-Zr alloys. Acta Materialia 2016, 111, 335-347. [CrossRef]

21. Issa, A.; Saal, J.E.; Wolverton, C. Formation of high-strength $\beta^{\prime}$ precipitates in Mg-RE alloys: The role of the $\mathrm{Mg} / \beta^{\prime \prime}$ interfacial instability. Acta Materialia 2015, 83, 75-83. [CrossRef]

22. Liu, H.; Xue, F.; Bai, J.; Zhou, J.; Sun, Y. Effects of heat treatments on microstructures and precipitation behaviour of $\mathrm{Mg}_{94} \mathrm{Y}_{4} \mathrm{Zn}_{2}$ extruded alloy. J. Mater. Sci. Technol. 2014, 30, 128-133. [CrossRef]

23. Suresh, M.; Srinivasan, A.; Pillai, U.T.S.; Pai, B.C. The effect of charcoal addition on the grain refinement and ageing response of magnesium alloy AZ91. Mater. Sci. Eng. A 2011, 528, 8573-8578. [CrossRef]

24. Ansari, M.A.; Behnagh, R.A.; Lin, D.; Kazeminia, S. Modelling of friction stir extrusion using artificial neural network (ANN). Int. J. Adv. Des. Manuf. Technol. 2018, 11, 1-12.

25. Okuyucu, H.; Kurt, A.; Arcaklioglu, E. Artificial neural network application to the friction stir welding of aluminum plates. Mater. Des. 2007, 28, 78-84. [CrossRef]

26. Asadi, P.; Givi, M.K.B.; Rastgoo, A.; Akbari, M.; Zakeri, V.; Rasouli, S. Predicting the grain size and hardness of AZ91/SiC nanocomposite by artificial neural networks. Int. J. Adv. Manuf. Technol. 2012, 63, 1095-1107. [CrossRef]

27. Yousif, Y.K.; Daws, K.M.; Kazem, B.I. Prediction of friction stir welding characteristic using neural network. Jordan J. Mech. Ind. Eng. 2008, 2, 151-155.

28. Ghetiya, N.D.; Patel, K.M. Prediction of tensile strength in friction stir welded aluminium alloy using artificial neural network. Procedia Technol. 2014, 14, 274-281. [CrossRef]

29. Arunchai, T.; Sonthipermpoon, K.; Apichayakul, P.; Tamee, K. Resistance spot welding optimization based on artificial neural network. Int. J. Manuf. Eng. 2014, 2014, 1-6. [CrossRef]

30. Habashy, D.M.; Mohamed, H.S.; El-Zaidia, E.F.M. A simulated neural system (ANNs) for micro-hardness of nano-crystalline titanium dioxide. Physica B 2019, 556, 183-189. [CrossRef]

31. Voort, G.F.; James, H.M. Metal Handbook: Metallography and Microstructures; American Society for Metals: Russel Township, OH, USA, 1989; Volume 9, pp. 425-434.

32. Abd El-Rehim, A.F.; Mahmoud, M.A. Transient and steady state creep of age-hardenable Al-5 wt $\% \mathrm{Mg}$ alloy during superimposed torsional oscillations. J. Mater. Sci. 2013, 48, 2659-2669. [CrossRef]

33. Celotto, S. TEM study of continuous precipitation in $\mathrm{Mg}-9 \mathrm{wt} \% \mathrm{Al}-1 \mathrm{wt} \% \mathrm{Zn}$ alloy. Acta Materialia 2000, 48, 1775-1787. [CrossRef]

34. Abd El-Rehim, A.F. Effect of cyclic stress reduction on the creep characteristics of AZ91 magnesium alloy. Acta Metallurgica Sinica (Engl. Lett.) 2015, 28, 1065-1073. [CrossRef]

35. Zheng, M.Y.; Wu, K.; Kamado, S.; Kojima, Y. Aging behavior of squeeze cast SiCw/AZ91 magnesium matrix composite. Mater. Sci. Eng. A 2003, 348, 67-75. [CrossRef]

36. Duly, D.; Brechet, Y.; Chenal, B. Macroscopic kinetics of discontinuous precipitation in a Mg-8.5wt.\% $\mathrm{Al}$ alloy. Acta Metallurgica Materialia 1992, 40, 2289-2300. [CrossRef]

37. Manna, I.; Pabi, S.K.; Gust, W. Discontinuous reactions in solids. Int. Mater. Rev. 2013, 46, 53-91. [CrossRef]

38. Robson, J.D. Modeling competitive continuous and discontinuous precipitation. Acta Materialia 2013, 61, 7781-7790. [CrossRef]

39. Busk, R.S. Effect of temperature on the lattice parameters of magnesium alloys. JOM 1952, 4, 207-209. [CrossRef]

40. Fatmi, M.; Djemli, A.; Ouali, A.; Chihi, T.; Ghebouli, M.A.; Belhouchet, H. Heat treatment and kinetics of precipitation of $\beta-\mathrm{Mg}_{17} \mathrm{Al}_{12}$ phase in AZ91 alloy. Res. Phys. 2018, 10, 693-698. [CrossRef]

41. Han, G.M.; Han, Z.Q.; Luo, A.A.; Liu, B.C. Microstructure characteristics and effect of aging process on the mechanical properties of squeeze-cast AZ91 alloy. J. Alloys Compd. 2015, 641, 56-63. [CrossRef]

(C) 2020 by the authors. Licensee MDPI, Basel, Switzerland. This article is an open access article distributed under the terms and conditions of the Creative Commons Attribution (CC BY) license (http://creativecommons.org/licenses/by/4.0/). 